\title{
Automatic Formulation of the Internal Control Report over Financial Reporting
}

\author{
Mohamed A. Wahdan, PhD * \\ Hatem A. Al-Shaarawy, PhD **
}

*Mohamed A. Wahdan, PhD Professor of Auditing and vice-dean of postgraduate studies and researches, Faculty of Commerce, Menoufia university, My research interests are Auditing, AIS, IT and Tax accounting.

**Hatem A. Al-Shaarawy Lecuturer in Accounting Department, Faculty of Commerce, Menoufia University, PhD. In accounting, Faculty of Economic Sciences, Goettingen University, Germany. My research interests are Financial Accounting, international Accounting and auditing. 


\section{Abstract :}

The evaluation of the internal controls over financial reporting is a difficult task which has to be learned over the years. Experience is a good teacher in this respect. So, education guided by experience may be expected to be fruitful. The purpose of this paper is to model, implement, and validate a knowledge-based system, called the "Auditor's Report on Internal Controls over Financial reporting" (ARICOFR), that is capable of formulating the opinion on the effectiveness of internal controls over financial reporting, as expressed in the auditor's report on internal controls over financial reporting. The main research questions studied in this study are: (1) can ARICOFR carry out the task of evaluating the internal controls over financial reporting equally as may be expected from an experienced auditor? If so, (2) how should ARICOFR be constructed and validated? And (3) to what extent is ARICOFR effective, efficient, and acceptable as a tool to help auditor evaluate the effectiveness of internal controls over financial Reporting? The knowledge used by ARICOFR is developed from the literature, and from qualified auditors through questionnaires and in-depth interviews. After putting into practice, the knowledge base is presented to experienced auditors for review. The ARICOFR performance is confirmed by test cases. From the consequences of the confirmation, we may conclude that ARICOFR is fruitful in performing the task of evaluating the internal controls over financial reporting.

تقييم الرقابة البحث : الخلية علي التقارير المالية هي مهمة صعبة يجب تعلمها علي مر السنين. وتعتبر

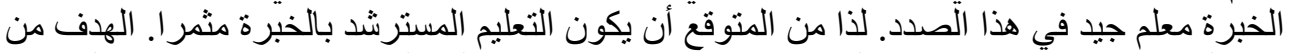

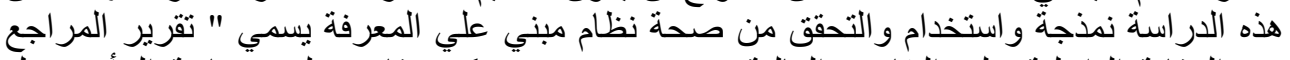

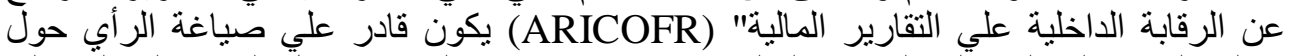

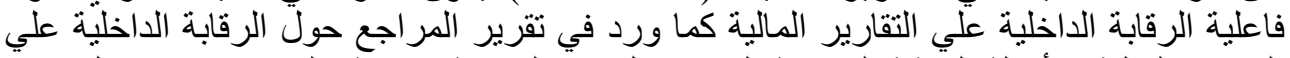

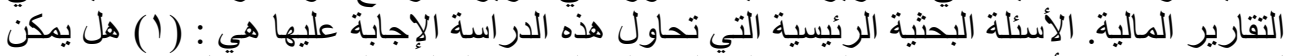

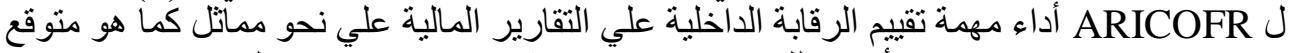

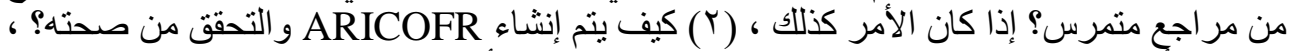
(r) إلي أي مدي يكون ARICOFR فعال وكفء ومقبول كأداة لمساعدة المر اجع علي تقييم فعالية الرقابة الداخلية علي التقارير المالية؟. يتم الحصول علي المعرفة المستخدمة من قبل ARICOFR

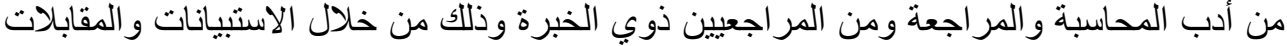

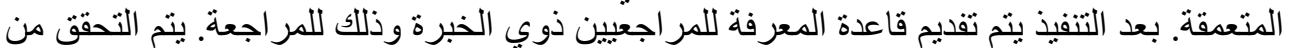

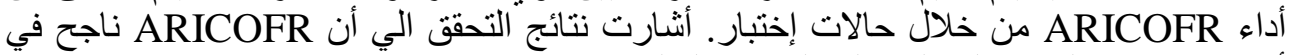
أداء مهمة تقييم الرقابة الداخلية علي التقارير المالية. 


\section{Introduction}

Management is responsible for establishing and maintaining the entity's internal controls over financial reporting. According to Section 404 of Sarbanes-Oxley Act, management is also required to publicly report on the operating effectiveness of internal controls over financial reporting. In contrast, the auditor of a public company is required by Section 404 of SOX Act to attest management's report on the effectiveness of internal controls over financial reporting. Since 2004, larger public companies have been required by the SEC to annually obtain an auditor's report on internal controls over financial reporting (Lopez, Vandervelde \& Wu, 2006; Institute of Internal Auditors, 2008; Romney \& Steinbart, 2012; Arens et al., 2014). The PCAOB's protocol to require the Audit of the firm's Internal control over financial reporting (ICOFR) system and make that evaluation public information seems to be an excellent corrective (Gaber, Garas, Luck, 2019).

Standard unqualified audit report loses some credibility when it is combined with an adverse entity-level internal controls over financial reporting report as alleged by some users (Asare and Wright, 2012). Section 404 of the Sarbanes-Oxley Act stated that each annual report contains an internal control report, which shall (1) state the responsibility of management for establishing and maintaining an adequate internal control structure and procedures for financial reporting; and (2) contain an assessment of the effectiveness of the internal control structure and procedures of the issuer for financial reporting.

Since company managers and auditors depend on their personal judgments during the stage of evaluating the internal controls, this may lead to different company managers and auditors reaching different decisions on the effectiveness of internal controls over financial reporting, depending on, among others, their experience and expertise (Curtis and Hayes, 2002; O'Leary, 2003).

To formulate their opinions on the management's assessment of internal controls over financial reporting, auditors use a "personaljudgment" method. In performing so, they greatly depend on their own experience and expertise. Such a method may be ineffective and may cause different auditors coming to different decisions, developing an individual 
bias, increasing/decreasing audit scope, and/or giving misleading judgments.

To overcome the deficiencies of a "personal-judgment" approach, auditors can do an electronic evaluation and formulation of the opinion of internal controls over financial reporting by a computer program, as a knowledge-based system (KBS). But the intriguing question is: can a computer program support the managers to evaluate the effectiveness of internal controls and to help auditors evaluate the management's assessment on the internal controls over financial reporting? We can summarize the study problem by the following questions: (1) can ARICOFR perform the task of evaluating the internal controls over financial reporting equally as may be expected from an practiced auditor? (2) how could ARICOFR be constructed and confirmed? An (3) to what extent is ARICOFR effective, efficient, and acceptable as an instrument to help auditor evaluate the effectiveness of internal controls over financial Reporting?

A computer program, as a knowledge-based system (KBS), may be capable to evaluate the internal controls and formulate the opinion on internal controls over financial reporting and does so sufficiently will reduce the inconsistencies of the individual judgments (cf. Brown and Murphy, 1990; Flory, 1991; O'Leary, 2003). Hence, an electronic evaluation and formulation of the opinion of internal controls over financial reporting by a computer program, as a knowledge-based system (KBS), may provide five benefits: (1) preservation of expertise, (2) efficiency, (3) training, (4) effectiveness, and (5) improving an auditor's ability (Wahdan, 2006). It may expedite auditors' opinions on internal controls over financial reporting, thus expressing those opinions more dependable.

Moreover, a KBS for such a job could also be used as an internal training instrument at auditing firms to form the experience of junior auditors. It will help managers detect the weaknesses in their organizations' internal controls more effectively and efficiently and prepare the assessment of internal controls as required by section 404 of SOX act. It may help the developing countries comply with international standards and apply the rules of Sarbanes Oxley act to decrease the fraud and corruptions in financial and managerial aspects. It will increase the likelihood that the auditors' opinions on internal controls over financial reporting comply with 
the International Standards on Auditing (ISA) (IFAC, 2010), components of COSO's internal control model, Sarbanes Oxley act (Krishnan \& Visvanathan, 2007) or any other similar acts. This study examines to what extent it is possible to computerize the evaluation of the internal controls over financial reporting with a KBS. This KBS will help auditor to evaluate the management's evaluation on the internal controls over financial reporting according to SOX act.

In our examination, we established a KBS called the "Auditor's Report on internal controls Over Financial Reporting" (ARICOFR), which is able to evaluate the internal controls over financial reporting. ARICOFR contains all knowledge associated with the auditor's opinion on both the effectiveness of internal controls and the management's assessment on the internal controls over financial reporting. ARICOFR is directed in particular to the auditing practice in Egypt. This nation may have only a limited number of qualified auditors who are sufficient in evaluating the internal controls, in particular in E-Commerce environment (Wahdan, et al., 2005; Wahdan, \& Van den Herik, 2012).

To progress ARICOFR, knowledge was collected from the literature and from a suitable set of qualified auditors through questionnaires and indepth interviews. The initial validation consequences acquired from qualified auditors in Egypt, using investigation cases and in-depth interviews, indicate that ARICOFR successfully achieves the task of evaluating the effectiveness of internal controls over financial reporting.

The outline of the paper is as follows. Section 2 deals with literature review. Section 3 presents the research methodology. Section 4 describes the conceptual model of ARICOFR. Section 5 deals with the actual implementation of ARICOFR. Section 6 shows the validation and evaluation. Section 7 discusses the research limitations. Section 8 illustrates our main conclusions and point at forthcoming study.

\section{Literature Review}

KBS has been applied to an abundance of decision problems in financial and production domains, such as for supporting investments decisions (see Poh, 2000), for performance measurement (Ammar, Duncombe, Jump, \& Wright, 2004; Khan \& Wibisono, 2008; Wang, Huang, \& Lai, 2008), for 
formulating budget planning - which is called Knowledge-based Intelligent Decision Support System or KIDSS system (Wen et al., 2005), for supporting business in small financial institutions (Chung \& Pak, 2006), for supporting decision on credit granting - which is called Moody's KMV Risk Advisor $^{\mathrm{TM}}$ or MRA (Kumra et al., 2006), for formulating the auditor's opinion - which is called Auditor Report EXpert or AREX (Wahdan, 2006), for optimising portfolio management (Bao \& Yang, 2008), for measuring logistic performance - which is called knowledge-based logistics performance measurement system or KLPMS (Choy et al., 2008), for financial knowledge management (Shiue et al., 2008; Cheng et al., 2009), for evaluating the credit worthiness of customers using balance scorecard strategic planning opinions - which is called BSC knowledge-based system or BSCKBS (Huang, 2009), for selecting supplier/customer with the consideration of benefits, opportunities, costs, and risks (Lee, 2009), for determining cost-volume-profit analysis (Yuan, 2009), for determining (pro)-performance appraisal (Chen \& Chen, 2010), for obtaining customerbuying patterns (Jayanthi \& Vishal, 2011) and for clarifying financial ratios (Gunawan, 2012), for assessing materiality level at the audit planning stage Materiality Expert (MEX) (Wahdan \& Hassan, 2019).

While organizations develop information systems, auditors must adapt their approaches to comply with the fast evolution of these systems. Auditors need computerized tools and techniques to improve the audit process (Egerdahl, 1995). The need for KBSs in different areas, in particular in auditing, is one avenue for improving an organization's competitive edge with less cost and lower risk (Mattei, 2001; Killingsworth, Hayden, and Schellenberger, 2001; Gunawan, 2012). The audit is a decision process. It can be divided into four categories namely: (1) an information acquisition decision, (2) a design activity, (3) an opinion decision or choice, and (4) an action (cf. Jacob and Bailey, 1991; Brown and Eining, 1997; Wahdan, 2006; Gunawan, 2012).

The audit process includes 4 phases: (1) planning and designing an audit method, (2) performing tests of controls, (3) performing analytical procedures and tests of details of transactions and balances, and (4) completing the audit and issuing the auditor's report (Arens et al., 2014). In terms of functional areas, Brown and Murphy (1990) \& Vinze and Karan 
(1991) differentiate 3 areas where a KBS can enhance the audit process: (1) the audit program development, (2) the internal control assessment and risk analysis, and (3) the technical support.

In this research, we remark that previous KBSs in auditing are classified into four categories, which correspond to four audit phases: (1) audit planning (audit phase 1), (2) internal-controls evaluation (audit phase 2), (3) going-concern uncertainties (audit phase 4), and (4) auditor's opinion (audit phase 4). These systems are briefly presented as follows. (1) Audit planning systems that relate to the first audit phase include (1a) AUDITPLANNER (Steinbart, 1987) and (1b) CAPEX (Boritz and Wensley, 1992, 1996) (1c) Materiality Expert (MEX) (Wahdan \& Hassan, 2019). (2) Internal-controls evaluation systems that relate to the second audit phase and include (2a) EDP-XPERT (Hansen and Messier, 1992), (2b) INFAAUDITOR (Akoka and Comyn-Wattiau, 1996, 1997), and (2c) INTERNAL CONTROL KNOWLEDGE (Changchit, Holsapple, and Viator, 2001). (3) Going-concern uncertainties systems that relate to the final audit phase include (3a) GC ADVISOR (Lenard et al., 1998) and (3b) HYBRID GC ADVISOR (Lenard et al., 2001). (4) The auditor's opinion systems that relates to the final audit phase are: (4a) AOF (Hegazy, 1992), (4b) AUDPORT (Smith and McDuffie, 1996) and (4c) AREX (Wahdan, 2006).

Consistent with Auditing Standard No. 5, (Asare, et al. 2013) delineate five phases of the ICOFR audit: (1) planning; (2) scoping; (3) testing; (4) evaluation; and (5) reporting. With regarding to Internal-controls evaluation systems (our main concern), there are three systems as follows.

\section{(2a) EDP-XPERT}

In 1992, Messier and Hansen continued the evaluation of EDP-XPERT developed by them in 1986 (EDP-XPERT is an expert system for assisting computer audit specialists' judgements on the reliability of controls in advanced computer environments). The results of that evaluation indicated that EDP-XPERT performed well on test cases but its performance declined on actual audits (Messier and Hansen, 1992).

(2b) INFAAUDITOR

Fifteen years ago, Akoka and Comyn-Wattiau $(1996,1997)$ presented the INFAAUDITOR to aid the auditor in auditing management information 
systems. The knowledge base consists of the characteristics of the enterprise, its information system, and the audit objectives. The rule bases encompassed the criteria, the general audit tree, and the rules of customization. INFAAUDITOR was successfully applied to several real-life situations.

\section{(2c) INTERNAL CONTROL KNOWLEDGE}

Changchit, Holsapple, and Viator (2001a) developed an expert system to facilitate the transfer control knowledge to management. The findings of the study indicated that the expert system could help managers to detect the weaknesses in their organizations' internal controls more effectively and efficiently. Changchit, Holsapple, and Madden (2001b) developed another study for the same purpose with results similar to the former. Both studies have two restrictions arising from their limited scope. First, they concentrate only on the evaluation of controls commonly found in the sales and collection cycle in the merchandising industry. Second, the knowledge of this system is based on one auditor's experience (expert specific).

Hwang et al.(2004) presented a prototype design support model called "CRAS-CBR" using case-based reasoning to help auditors making their professional judgments on the control risk assessment of the accounting systems in the manufacturing industry. The results of the experiment indicated that CRAS-CBR outperforms staff auditor performance and a statistical model. However, this study depends only on a small sample size.

Marand and Bayaz (2015) purposed to discover the impact of computerized accounting systems on the auditing risk management in listed firms of Tehran stock exchange. The results of the study indicated that the computerized accounting system has a positive impact on the inherent risk in forms of reducing the internal control weakness, reducing the risk of sampling related to tests of controls and providing with a suitable method to assess the inherent risk.

Han et al. (2015) dealt with the association between information technology (IT) and audit risk. They found that the IT complexity generates challenges for auditors in evaluating the effectiveness of internal control and detecting accounting irregularities. However, IT decreases the audit risk by improving operations and internal control effectiveness which may decrease the inherent and control risks.

Davis et al. (2017) described a case approach for teaching internal control evaluation in sales and cash receipts cycles using Excel spreadsheet 
tool. The case and spreadsheet application provide students an opportunity to deeply understand and analyse the accounting processes, the internal controls, and the interrelationships between the processes and controls. The finding of the study indicated that the students were significantly increased their abilities to evaluate internal controls by completing the case (their average score increased from $44 \%$ to $62 \%$ ).

There are 3 main restrictions related to previously established KBSs made for an auditing area. They are: (1) the knowledge bases indicate only the expertise of a single practitioner, so the capability to generalize the system's conclusions is constrained (Changchit, Holsapple, \& Viator, 2001), (2) the KBSs do not indicate any real decision-making in auditing firms they achieve well on examination cases but their performance decreases on actual audit cases (Smith and McDuffie, 1996; Collier, Leech, \& Clark, 1999; Lenard, Alam, Booth, \& Madey, 2001; Lenard, 2003), and (3) they do not deal with the audit process as a whole, but concentrate instead on limited sides of the auditor's concern within a definite cycle (they do not consider the following sides: understanding internal controls environment, investigating management integrity, investigating control procedures, walking-through of significant accounts, tests of controls, and internal controls over financial reporting). Also, preceding studies disregarded the role of users in evolving a knowledge base and building an description facility (Akoka and Comyn-Wattiau, 1996; Mak, Schmitt, \& Lyytinen, 1997; Bayraktar, 1998; Changchit et al., 2001a).

So far, a whole KBS for expressing the auditor's opinion on internal controls over financial reporting received little attention in the literature. To the best of our knowledge, previous research has failed to deal adequately with the complexities of the task of evaluating the internal controls over financial reporting. Up till now, no single KBS has been developed which executes this task in practice, as we established during a survey among local and international auditing firms in the Middle East (a pilot study by the author).

\section{3- Research methodology}

To progress ARICOFR, knowledge was attained from the literature and from a proper set of qualified auditors through questionnaires and in-depth interviews, using the Knowledge Acquisition and Design Systems (KADS) 
method (cf. Schreiber, Wielinga, \& Breuker, 1993; Post, Wielinga, \& Schreiber, 1997). ARICOFR is applied using the Knowledge Representation Objects Language (KROL) (Shaalan, Rafea, \& Rafea, 1998). After application, the knowledge base was confirmed by qualified auditors. The auditors were determined relying on at least one of the following 3 items: (i) the number of years of experience (at least 10 years), (ii) the level of education (at least a bachelor degree of accounting and auditing), and (iii) some work performed in international auditing firms. A preliminary study was carried out to examine the clarity and validity of the questions in all questionnaire lists.

Part of the study is based on the two surveys conducted: (i) to elicit knowledge from auditors, and (ii) to validate and evaluate ARICOFR by Egyptian auditors and students. Our study was divided into the following seven steps.

1. The knowledge needed to build ARICOFR was learned from the literature.

2. The first questionnaire (knowledge elicitation) coupled with in-depth interviews, using the KADS methodology as a model-driven approach, was used to elicit the knowledge from experienced auditors in the audit firm.

3. The acquired knowledge was confirmed by allowing the auditors review the consequences of the knowledge-acquisition process. Differences between two or more auditors were first given to a small sample of the auditors for determination. If they could not reach agreement, the leading expert made the last decision.

4. A prototype of ARICOFR was constructed and implemented, using the KROL language, based upon the knowledge collected and elicited in the steps one and two, and reviewed in step three.

5. A primary confirmation of ARICOFR was approved in Egypt. A questionnaire was distributed to 40 auditors. The questionnaire contained mainly of twelve auditing cases that needed to be handled by the auditors as test cases. The test cases were handled by ARICOFR too, and the opinions of ARICOFR were compared to the auditors' opinions. In addition, five auditors who used the 
ARICOFR in hypothetical cases expressed their opinions on the performance of ARICOFR.

6. A final version of ARICOFR was implemented based on the findings of the preliminary validation, and an additional revision of the knowledge acquired in the first three steps, including the pilot study, and the first survey.

7. ARICOFR was run and was processed on test auditing cases by Master students. In addition, the questionnaire number 2 and indepth interviews were used to evaluate the effectiveness, efficiency, and acceptance of ARICOFR.

\section{Conceptual Model OF ARICOFR}

This section presents the evaluation of the internal controls (4.1), the internal controls over financial reporting (4.2) and the conceptual model of ARICOFR (4.3).

\subsection{Evaluation of the internal controls}

A company's manager is mainly concerned with presenting the results of the company's operations as acceptable as possible. This concern may conflict with the aim of preparing accounts to present a reasonable opinion. The auditor's report gives credibility to financial reports by confirming the methods and procedures used to report the company's findings (Guy, Carmichael, \& Lach, 2003; Arens et al., 2014). The auditor is responsible for examining the compliance with GAAP and for attesting that financial reports are fairly presented (Whittington and Pany, 2003; PCAOB, 2007; Hayes, Dassen, Schilder, \& Wallage, 2005; Boynton and Johnson, 2006). To do so, the auditor performs many tasks; from these tasks the evaluation of internal controls (ISA, 400) to determine the audit scope, as the auditing standard (ISA 400) requires that the auditor obtains adequate understanding of internal controls. If the auditor is convinced that the auditee has appropriate and adequate internal controls, the amount of audit evidence will be less than when internal controls are inadequate (Manson and Zaman, 2001; Locatelli, 2002; IFAC, 2010).

So, any program for examining control will aim at determining the control risk (CR), which seeks to determine internal controls' reliability and 
the amount of audit evidence required to support the assessment of the control risk. To assess the effectiveness of the internal controls for planning audit evidence, auditors need to understand the key internal controls and assess the control risk according to COSO's internal control model (IFAC, 2010; Arens et al., 2014).

\subsection{The internal controls over financial reporting}

According to some recent corporate scandals the Sarbanes-Oxley Act of 2002 (SOX) is issued. This Act required the disclosure of three new reports related to the effectiveness of a company's internal controls: (1) The management's report on the effectiveness of the internal controls, (2) the auditor's opinion on the management assessment of the effectiveness of internal controls (the auditor will issue an unqualified opinion on the management's assessment of internal controls if he agrees with management's assessment, and will issue an adverse opinion if he does not agree with the management's assessment), and (3) the auditor's opinion on the effectiveness of internal controls (the auditor will issue an unqualified opinion on the effectiveness of internal controls if there are no material weakness in the internal controls, and will issue an adverse opinion if there are material weakness in the internal controls) (Lopez, Vandervelde, \& Wu, 2006). After SOX was passed, the management must: (a) base its evaluation on COSO's internal control model, (b) disclose all material internal controls weaknesses, and (c) conclude that a company does not have effective financial reporting internal controls if there are material weaknesses (Romany \& Steinbart, 2012). The five interrelated components of COSO's internal control model are Control environment, risk assessment, Control activities, information and communication, and monitoring (Arens, et al., 2014; Romany \& Steinbart, 2012). PCAOB auditing standard 5 requires the audit of internal control to be integrated with the audit of the financial statements (See figure 1). However, the auditor may choose to issue separate report or a combined report (PCAOB, 2007; Arens, et al., 2014). 


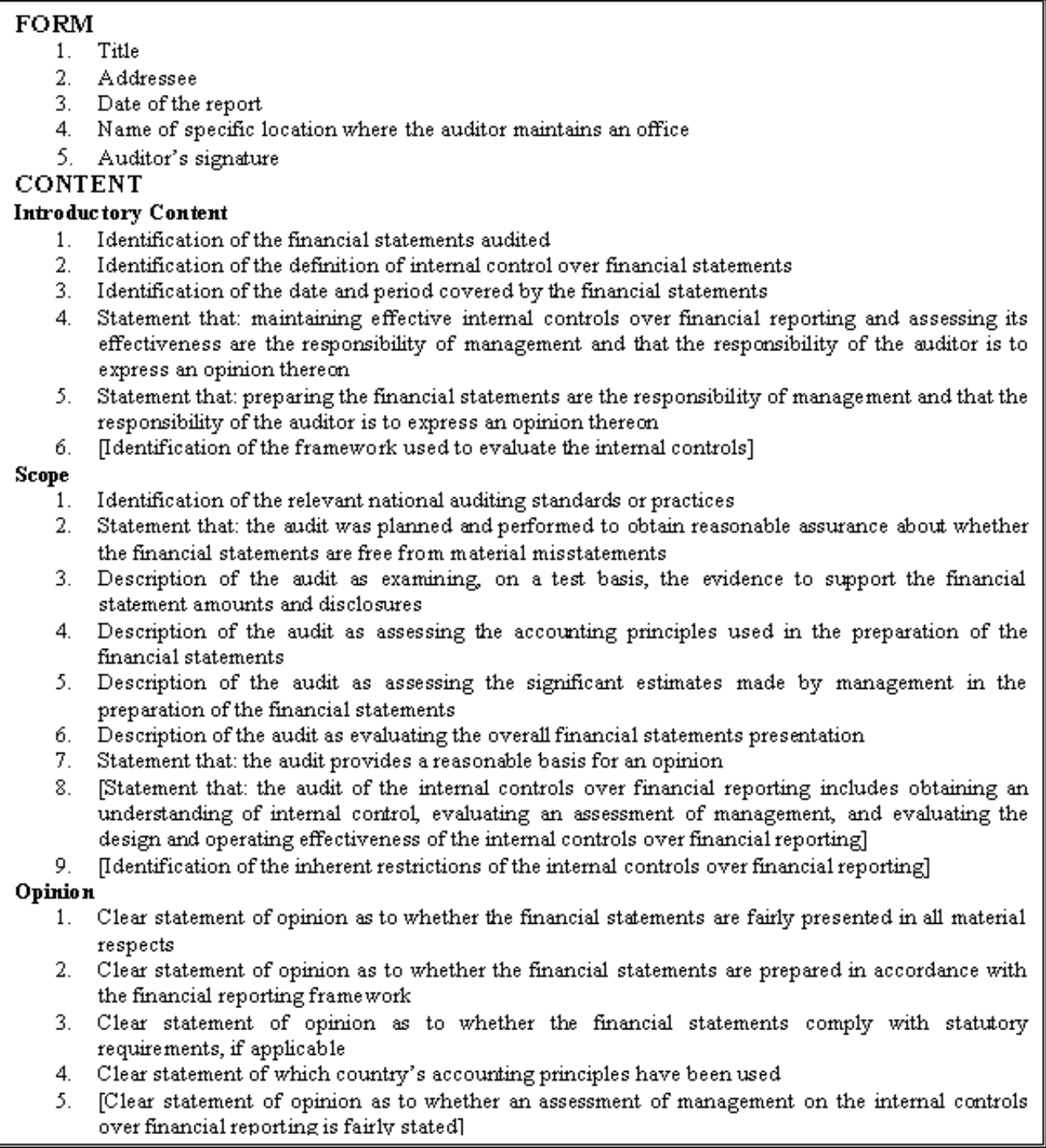

\section{Figure 1: Elements of the auditor's report according to the ISA 700 and [Section 404]. \\ The latter ones are given in square brackets [ ] Sources: PCAOB (2007) adapted.}




\subsection{Conceptual Model Structure}

Our conceptual model structures the process of examining and determining the control risk (CR), which seeks to determine internal controls reliability and amount of audit evidence required to support the assessment of the control risk. To assess the effectiveness of the internal controls for planning audit evidence, auditors need to understand the key internal controls and assess the control risk. It is common practice that if the auditors rely on the internal controls, they will reduce the amount of substantive tests, which they have to execute (Arens et al., 2012). A common approach used by auditors, to determine the reliability of the internal controls, consists of three stages: (1) obtaining an understanding of the internal controls at a detailed level, (2) assessing the control risk and identifying the possibility of reducing it, and (3) testing the effectiveness of the internal controls. An auditor may not conclude that the control risk is low before completing all these three stages (Locatelli, 2002: Guy et al., 2003; Arens et al., 2014, Wahdan, 2018).

To complete the test of evaluating internal controls, the conceptual model of ARICOFR distinguishes many sub-models (see Figure 2). Figure 2 illustrates the steps required to evaluate the effectiveness of internal controls and assess the control risk. The arrows in Figure 2 indicate that the output from one of the submodels is used as input for the other. For example, the output of the submodel of understanding internal controls forms the input of the following submodels: assessing management integrity, examining documents and records, and investigating management attitude.

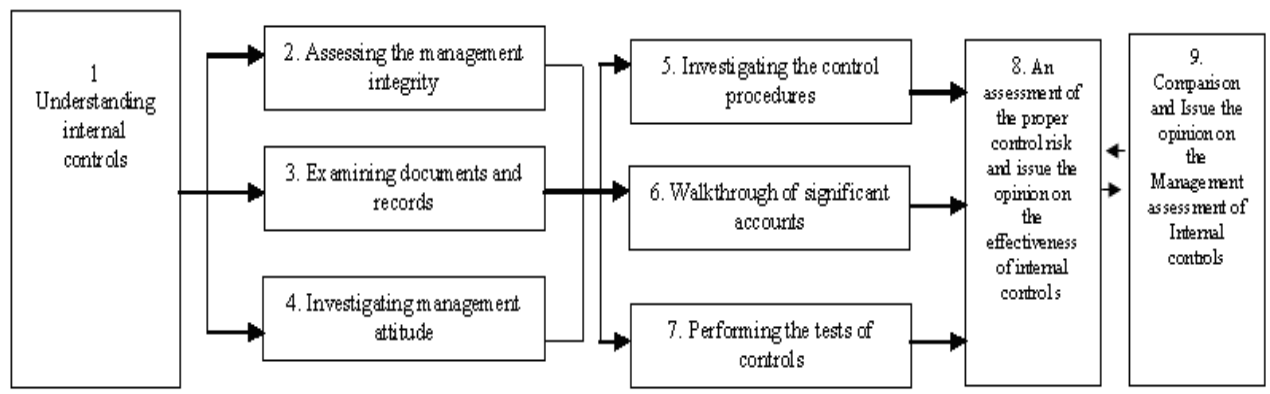

Figure 2: The conceptual model of ARICOFR. 
We list the nine sub-models together with a short explanation as the following:

(1) The submodel of understanding internal controls provides an understanding of the control environment and accounting system sufficient to set up the audit plan of financial statements (Guy et al., 2003; Boynton and Johnson, 2006; Arens et al., 2012). They have to be concerned with the controls regarding the reliability of financial reporting to comply with the second GAAS fieldwork, the SAS 78 (Lenard, 2003), the ISA 330, and the ISA 400 (IFAC, 2010). The SAS 78 and ISA 400 require the auditor to obtain an understanding of the internal controls for every audit. In obtaining an understanding of internal controls, the auditor should consider two issues, viz. the design of controls and their placement in operation (Arens et al., 2014). Auditors can use five procedures to evaluate the design of controls and placement in the operation: (1) updating and evaluating an auditor's previous experience with the company, (2) making inquiries of the auditee personnel, (3) reading an auditee's policy and systems manuals. (4) Examining documents and records, (5) observing the company activities and operations (PCAOB, 2007; Arens et al., 2014). The transaction walk-through can combine observation, documentation, and inquiry. The auditor selects a representative sample of documents for the initiation of a transaction type and traces them through the entire accounting process in the transaction walk-through (Ernst and Young, 2002; Arens et al.,2014) (See Figure 5 and information available from the authors).

(2) The management integrity submodel contributes to assess whether the financial statements are auditable. For example, in figure 5 (middle), the management integrity are affected by many factors. Some factors indicate a lack of management integrity, including the presence of one or a few individuals dominating management of the enterprise, improper accounting system, improper internal controls, false earnings, poor reputation, considerable turnover in senior positions, taking unusual risks, or poor relationships with auditors, customers, stockholders, and/or employees. If management integrity is questionable, false representations cause the auditor to rely on unreliable evidence. 
(3) The submodel of assessing the adequacy of documents and records contributes to assess whether the financial statements are auditable, if the accounting records (source of the audit evidence) are unreliable and/or inadequate, the audit evidence may not be accessible. When the auditor concludes that the financial statements are not auditable, the engagement is withdrawn or a disclaimer of opinion is issued (Arens et al., 2014).

(4) The submodel of investigating management attitude (control environment) checks actions, policies, and procedures that affect management attitudes with respect to internal controls. The auditor should understand the control environment to assess the management's attitude and awareness regarding the controls importance (Colbert, 2000; Munter, 2003; IFAC, 2010).

(5) The submodel of control procedures tests efficiency of controls activities. As shown in figure 5, control activities include adequate segregation of duties, proper authorisation of transactions and accounts, adequate documents and records, safeguarding controls, and independent checks on performance (Changchit, and Holsapple, and Viator, 2001, Arens et al., 2014), if management gives less attention to internal controls, the control activities may be unreliable and the control risk should be at the maximum.

(6) The submodel of walk-through of significant accounts tests whether the results of investigating the significant accounts supports the low assessment of control risk (Ernst \& Young, 2002; Arens et al., 2014).

(7) The tests of controls submodel evaluates whether the internal controls are designed and operated as contemplated in the preliminary assessment of control risk (Arens et al., 2014). The auditor should obtain audit evidence through tests of controls to support any assessment of control risk below the maximum. The lower the assessment of control risk, the more support the auditor should obtain that internal controls are suitably designed and effectively operated.

(8) The control risk submodel assesses the proper control risk after collecting the outputs from all the above submodels. If the auditor identifies the assessed level of control risk as the maximum, the conclusion should be documented. However, if it is below the maximum, the bases and reasons of that conclusion should be documented (Guy et 
al., 2003; Boynton and Johnson, 2006; Arens et al., 2014) (See figures 3 and 5).

(9) The auditor's opinion on management assessment submodel assesses whether the auditor agrees with the management assessment of internal controls. This submodel compares the output of submodel (8) with the management assessment of the effectiveness of internal controls and formulates the opinion on internal controls over financial reporting (See figures 2, 4 and 5).

\section{ARICOFR Implementation}

Knowledge acquiring is the extraction of knowledge from experts. It is a primary bottleneck to the development of dependable and practically usable KBSs (Jones and Miles, 1998). Therefore, the knowledge needed to construct ARICOFR was attained from the literature on ISA (IFAC, 2010), academic resources, journals, and from the qualified auditors. The knowledge acquisition process was designed according to the KADS methodology, using the submodels specified in the preceding section. In the development phase, knowledge was elicited from 40 qualified auditors during interviews. Questionnaire No. 1 (available from the authors) was designed to acquire the qualified auditors' knowledge and classified into nine parts, each covering one submodel. The attained knowledge was confirmed and differences between the auditors were resolved.

It is observed that knowledge engineers are using shells and devoted AI languages (Van den Herik, 1988) that contributes to accomplish the task. Thus, we use KROL (Shaalan, et al., 1998) to represent the ARICOFR knowledge. KROL combines object and rule processing. This combination allows the task of expressing the auditor's opinion on internal control over financial reporting to be classified into appropriate frameworks for more effective programming and system operation. To represent the ARICOFR knowledge, we used concepts, properties, prompts, values, and value sources. 


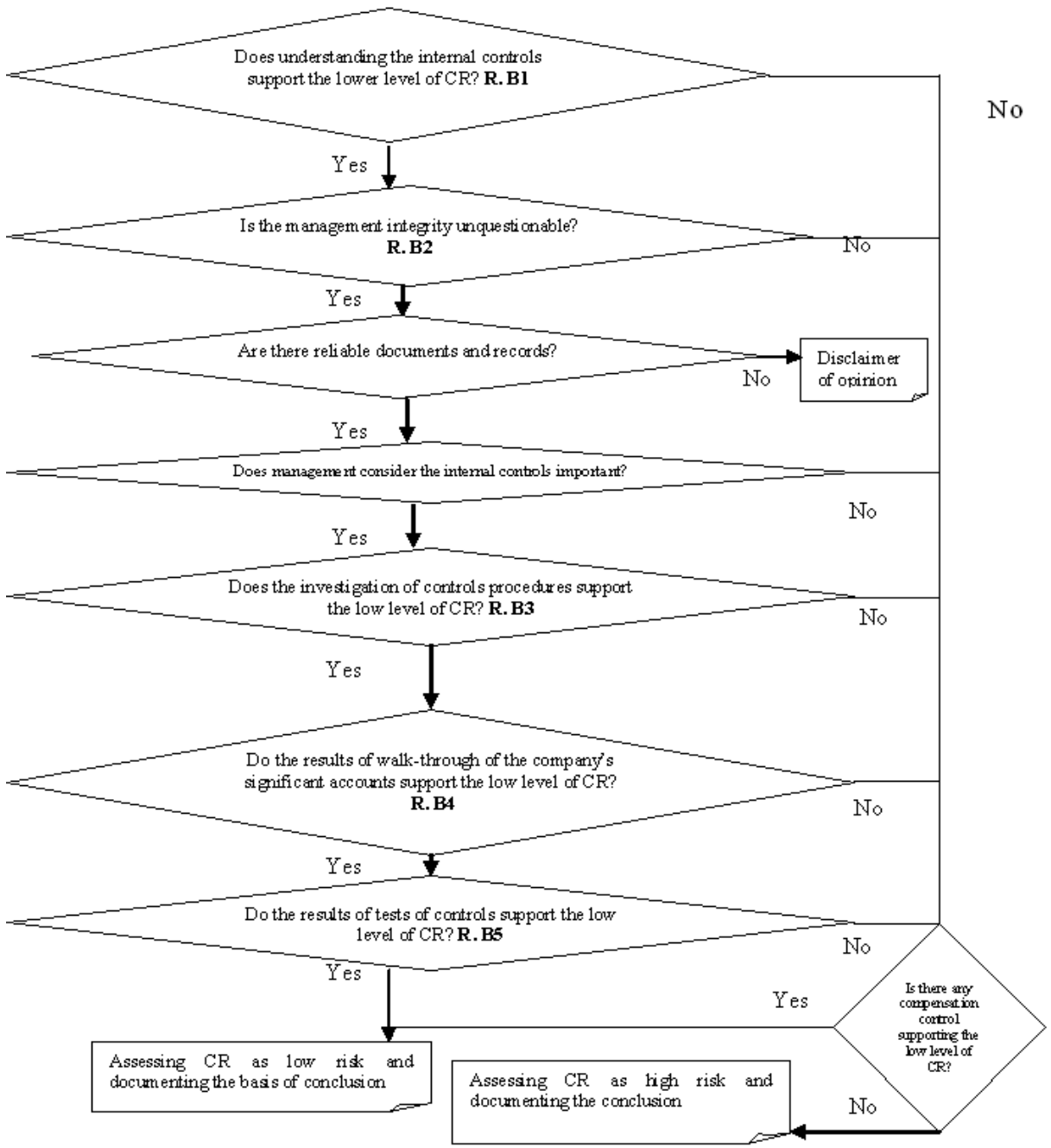

Figure 3: The model of examining controls. R.B1, 2,3,4,5 means Relations B1, 2,3,4,5 (from the authors) 


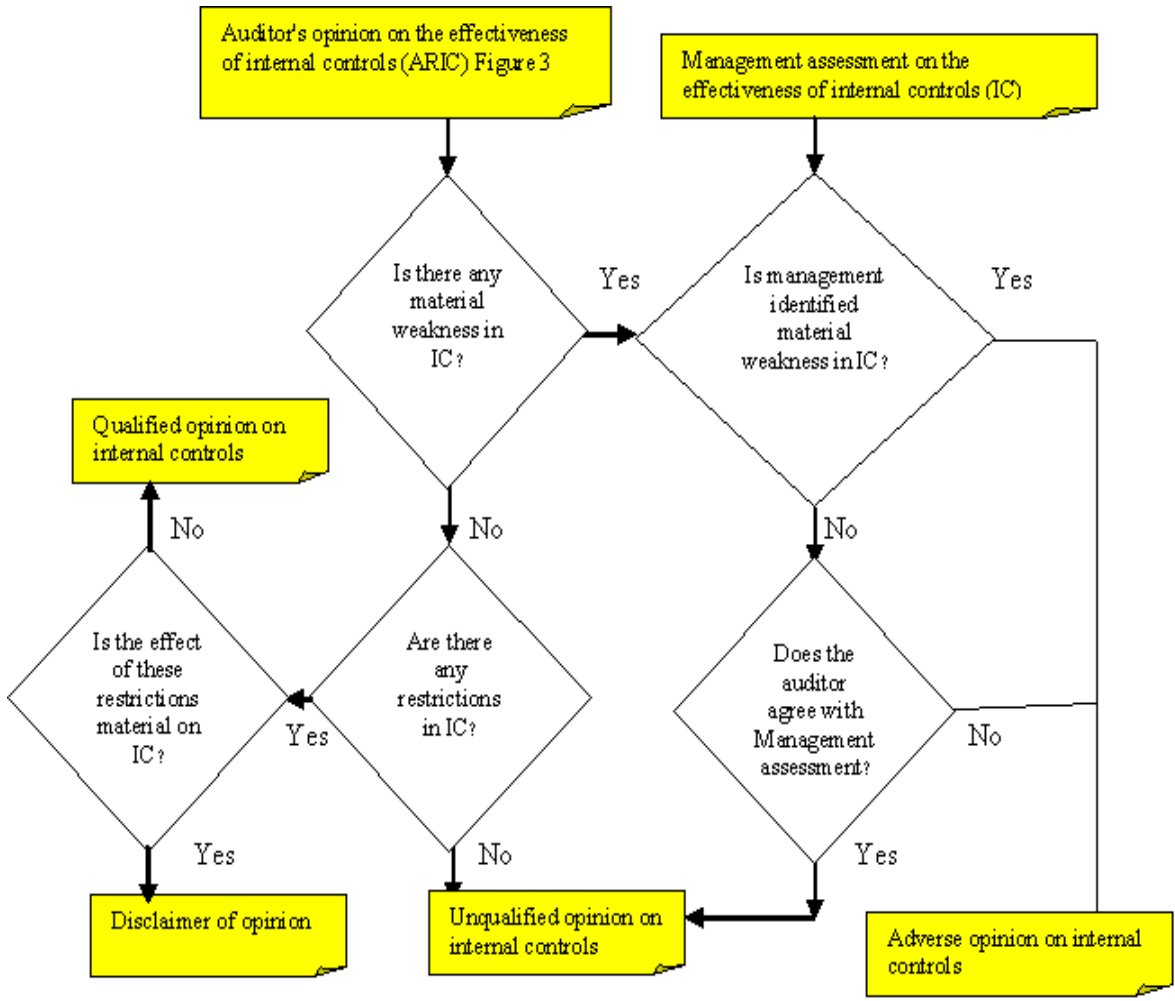

Figure 4: The Auditor's opinion on internal controls over financial reporting

The ARICOFR expertise framework differentiates between three kinds of knowledge:

First, the area knowledge comprises the knowledge needed for preparing the auditor's report on internal control over financial reporting. The ARICOFR area knowledge is kept in a concept hierarchy comprising of items with their relations. Questionnaire no 1 (available from the author) is used to acquire knowledge from the experienced auditors. Figure 5 depicts the ARICOFR concept hierarchy. 


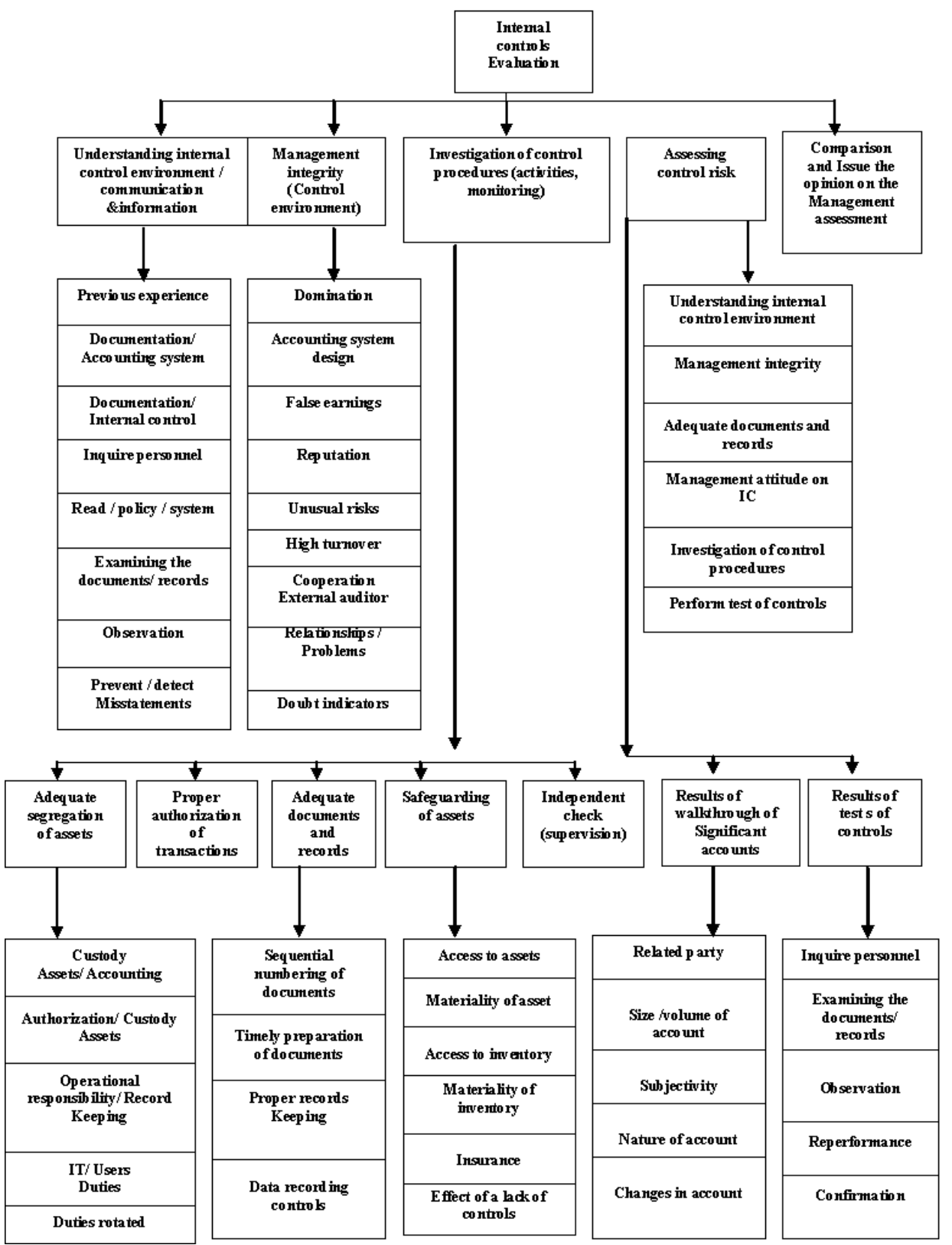

Figure 5: ARICOFR concept hierarchy. 
Second, the interpretation knowledge includes knowledge that is used in the reasoning process (Brown and O'Leary, 1995). We used programmed rules. ARICOFR produces the appropriate auditor's opinion on internal control over financial reporting by implementing user-supplied facts to the programmed rules. Third, the task knowledge is knowledge on the expressing of the auditor's opinion on internal control over financial reporting and the appropriate activities. In ARICOFR, the nine sub-models are used to construct the information that the user must supply. Table 1 shows the main concepts and sub-concepts. Each concept has properties, prompts (questions), values, and value sources.

Table 1: model of examining controls

\begin{tabular}{|c|c|c|c|c|}
\hline Concept & Property & Prompt & Value & $\begin{array}{l}\text { Source_of } \\
\text { Value }\end{array}$ \\
\hline \multirow[t]{6}{*}{$\begin{array}{l}\text { control__ } \\
\text { risk }\end{array}$} & $\begin{array}{l}\text { controls_design_- } \\
\text { operation_advice }\end{array}$ & $\begin{array}{l}\text { Understanding of } \\
\text { internal control }\end{array}$ & $\begin{array}{l}\text { Supports the low } \\
\text { level of control risk / } \\
\text { does not support the } \\
\text { low level of control } \\
\text { risk }\end{array}$ & $\begin{array}{l}\text { Derived / } \\
\text { relation B1/ } \\
\text { understanding } \\
\text { _internal } \\
\text { controls }\end{array}$ \\
\hline & $\begin{array}{l}\text { management_ingerity } \\
\text { advice }\end{array}$ & $\begin{array}{l}\text { The management } \\
\text { integrity }\end{array}$ & $\begin{array}{l}\text { Was questionable / } \\
\text { Was unquestionable }\end{array}$ & $\begin{array}{l}\text { Derived / } \\
\text { relation B2 / } \\
\text { management_- } \\
\text { Performance }\end{array}$ \\
\hline & $\begin{array}{l}\text { a-reliable_documents_ } \\
\text { records }\end{array}$ & $\begin{array}{l}\text { Are there reliable } \\
\text { documents and } \\
\text { records? }\end{array}$ & Yes / No & User \\
\hline & $\begin{array}{l}\text { b- } \\
\text { management_attitude }\end{array}$ & $\begin{array}{l}\text { Does management } \\
\text { consider internal } \\
\text { control important? }\end{array}$ & Yes / No & User \\
\hline & $\begin{array}{l}\text { control_procedures. } \\
\text { Advice }\end{array}$ & $\begin{array}{l}\text { Control } \\
\text { procedures }\end{array}$ & $\begin{array}{l}\text { Support the low level } \\
\text { of control risk / does } \\
\text { not support the low } \\
\text { level of control risk }\end{array}$ & $\begin{array}{l}\text { Derived / } \\
\text { relation B3 / } \\
\text { investigation_ } \\
\text { control_ } \\
\text { procedure }\end{array}$ \\
\hline & $\begin{array}{l}\text { walk-through_} \\
\text { significant_processes }\end{array}$ & $\begin{array}{l}\text { Walk-through of } \\
\text { Significant } \\
\text { processes }\end{array}$ & $\begin{array}{l}\text { Supports the low } \\
\text { level of control risk / } \\
\text { does not support the } \\
\text { low level of control } \\
\text { risk }\end{array}$ & $\begin{array}{l}\text { Derived / } \\
\text { relation B4/ } \\
\text { significant_ } \\
\text { accounts }\end{array}$ \\
\hline
\end{tabular}


Table 1: model of examining controls

\begin{tabular}{|c|c|c|c|c|}
\hline Concept & Property & Prompt & Value & $\begin{array}{c}\text { Source_of } \\
\text { Value }\end{array}$ \\
\hline \multirow[t]{4}{*}{$\begin{array}{l}\text { control_ } \\
\text { risk }\end{array}$} & $\begin{array}{l}\text { test_controls_support_ } \\
\text { low }\end{array}$ & Tests of controls & $\begin{array}{l}\text { Support the low } \\
\text { level of control } \\
\text { risk / do not } \\
\text { support the low } \\
\text { level of control } \\
\text { risk }\end{array}$ & $\begin{array}{l}\text { Derived } \\
\text { /relation B5 / } \\
\text { tests of controls } \\
\text { results }\end{array}$ \\
\hline & c_compensation_controls & $\begin{array}{l}\text { Is there any } \\
\text { compensation } \\
\text { control supporting } \\
\text { the low level of } \\
\text { control risk? }\end{array}$ & Yes / No & User \\
\hline & \multirow[t]{2}{*}{ Advice } & $\begin{array}{l}\text { Level of control } \\
\text { risk is }\end{array}$ & $\begin{array}{l}\text { maximum, } \\
\text { document } \\
\text { conclusion } \\
\text { below } \\
\text { maximum, } \\
\begin{array}{l}\text { document } \\
\text { basis } \\
\text { conclusion }\end{array}\end{array}$ & \multirow[t]{2}{*}{$\begin{array}{l}\text { Derived/ } \\
\text { model } 1 / \text { the_ } \\
\text { submodel } 8 \\
\text { model_of_- } \\
\text { examining_- } \\
\text { controls }\end{array}$} \\
\hline & & $\begin{array}{l}\text { The auditor is } \\
\text { advised to } \\
\text { formulate his } \\
\text { opinion as }\end{array}$ & $\begin{array}{l}\text { Disclaimer of } \\
\text { opinion, auditor } \\
\text { is not } \\
\text { independent / } \\
\text { withdraw from } \\
\text { audit process, } \\
\text { unreliable } \\
\text { documents and } \\
\text { records }\end{array}$ & \\
\hline \multirow{2}{*}{$\begin{array}{l}\text { Auditor's } \\
\text { opinion } \\
\text { on } \\
\text { internal } \\
\text { controls }\end{array}$} & a.management_assessment & $\begin{array}{l}\text { Are the internal } \\
\text { controls effective? }\end{array}$ & Yes / No & $\begin{array}{l}\text { Management } \\
\text { report }\end{array}$ \\
\hline & b.auditor's opinion & $\begin{array}{l}\text { Is the any } \\
\text { agreement } \\
\text { between the } \\
\text { management } \\
\text { assessment and } \\
\text { the auditor } \\
\text { assessment of } \\
\text { internal controls }\end{array}$ & Yes/no & $\begin{array}{l}\text { Derived/ } \\
\text { submodel 8/ } \\
\text { control risk \& } \\
\text { submodel 9/ } \\
\text { management_ } \\
\text { assessment }\end{array}$ \\
\hline
\end{tabular}

Interaction with ARICOFR occurs through a user interface and an description facility. By the user interface, users can source ARICOFR with information in two different methods. The first method is by sequential questions posed by ARICOFR, i.e., ARICOFR queries the user on needed information. The second method is by sheet screens. The user can select the values and/or the order of values, which he/she would like to allocate to 
assets, and can so acquire information on how the system works, why assets are needed, and how middle conclusions are derived. It provides the possibility of removing any inappropriate items, of printing conclusions and their reasoning (See Table 2), of stopping the program, and of going to the preceding and next submodels (see Figure 6). As will as, the help screen of ARICOFR, shown in Figure 7, illustrates more description to the user concerning how ARICOFR operates and explains its conclusion.

Table 2: The value of the input and the output attributes.

'A model of examining controls (Investigation of control procedures)'

\begin{tabular}{||c||c|c|}
\hline \multicolumn{1}{|c|}{ Concept } & Property & Value \\
\hline \hline control_procedures & a_effective_supervision_controls_internal_auditors & yes \\
\hline \hline control_procedures & b_separation_custody_assets_accounting & yes \\
\hline \hline control_procedures & c_separation_authorisation_custody_assets & yes \\
\hline \hline control_procedures & d_separation_operational_responsibility_record_keeping & yes \\
\hline \hline control_procedures & e_separation_IT_users_duties & yes \\
\hline \hline control_procedures & f_duties_rotated & yes \\
\hline \hline control_procedures & g_pre_sequential_numbering_documents & yes \\
\hline \hline control_procedures & h_timely_preparation_documents & yes \\
\hline \hline control_procedures & i_proper_records_keeping & yes \\
\hline control_procedures & j_controls_data_recording & yes \\
\hline \hline
\end{tabular}

Output: Investigation of control procedures: 'supports the low level of control risk 


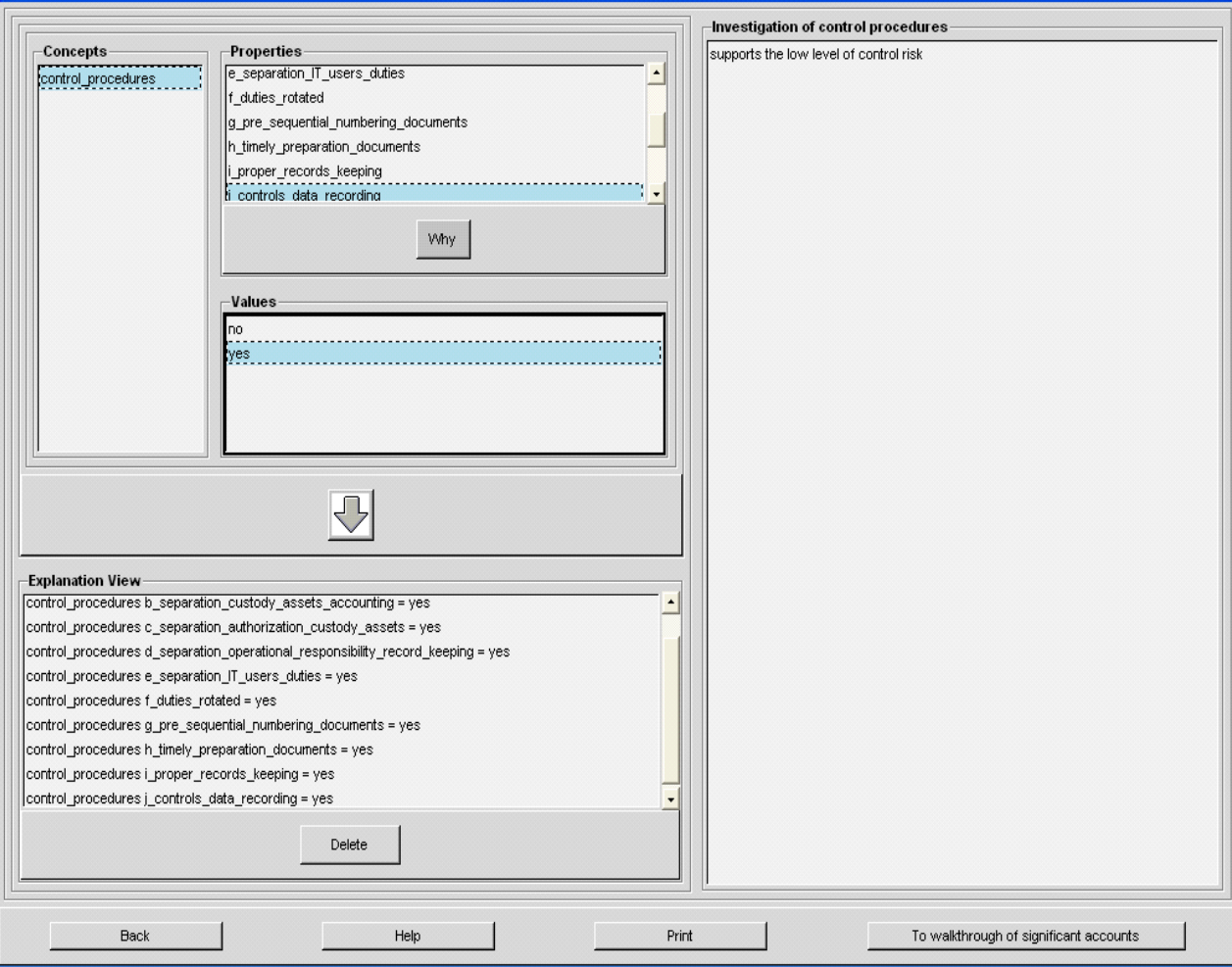

\section{Figure 6: Sheet screen.}

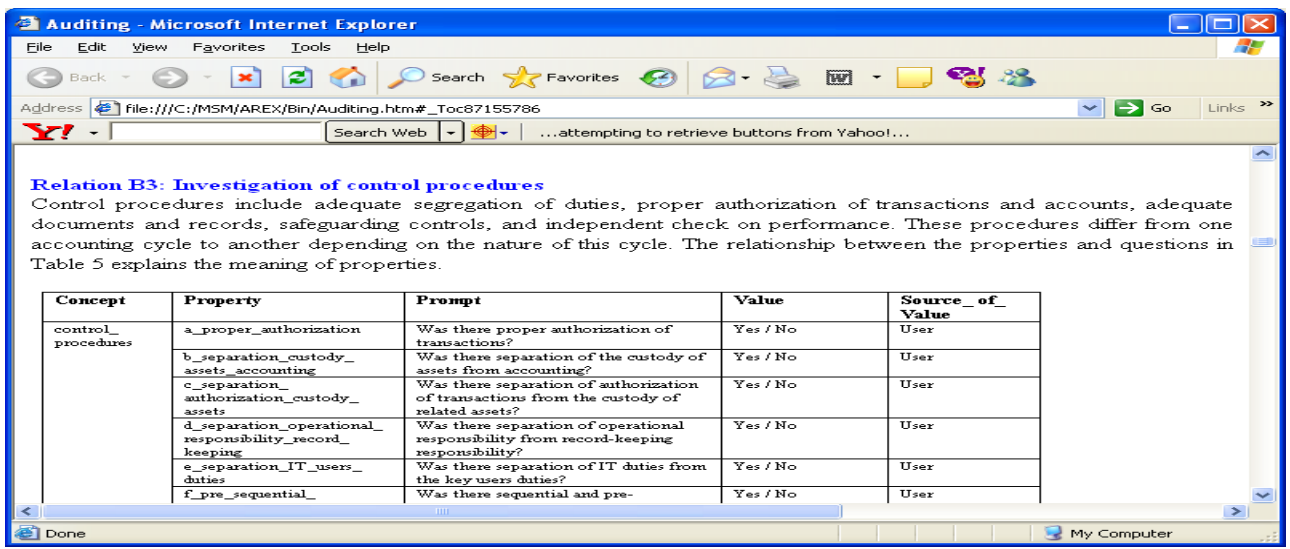

Figure 7: The help screen in ARICOFR. 


\section{Validation and Evaluation}

In the following we illustrate the validation and evaluation of ARICOFR. It begins with a primary validation (6.1), followed by an auditors' evaluation (6.2).

\subsection{Preliminary Validation}

Validation is an essential concept in the development, realisation, and implementation of a model (cf. Kumra et al., 2006). In particular, we may state that the validation process is crucial as we would like to know whether ARICOFR is functioning "as intended" (cf. Khan \& Wibisono, 2008). A primary validation of ARICOFR was achieved in Egypt as follows. First, questionnaire No. 2 (available from the authors) was distributed on 40 auditors. It consisted of twelve auditing cases that required to be handled by the auditors as assessment cases. These assessment cases were handled by ARICOFR too. Second, the results produced by ARICOFR were compared to the auditors' results. The results of the comparison showed that there was severely some $15 \%$ of differences in decisions between ARICOFR and the auditors. We discussed the reasons of the different decisions with the auditors. After discussion, we conclude that ARICOFR achieved better than the auditors; the auditors reviewed their decisions according to ARICOFR's results. Furthermore, we make some changes and improvements in ARICOFR. Third, five auditors were attracted to use the ARICOFR example in their own assumed cases. The results showed that ARICOFR achieved the task of assessing the internal controls in a manner identical to their own assessment.

\subsection{Auditors' Evaluation}

After the auditors had processed test auditing cases and review the logic of ARICOFR through ARICOFR flowcharts of the nine submodels, we choose a sample of twenty students who study a Master degree at Faculty of Commerce, Menoufia university in 2012 (their field is accounting and auditing). The students processed the test cases using ARICOFR. We examine their attitudes by questionnaire No. 3 (available from the authors) using five-point Likert scales (ranging from strongly agree $=5$ to strongly disagree $=1$ ). The examined data contain the students' assessment of 
ARICOFR's effectiveness (6.2.1), its efficiency (6.2.2), and its acceptance (6.2.3). A summary of the results is given in Table 3.

Table 3: Students' evaluation of ARICOFR

\begin{tabular}{|c|c|c|c|c|c|c|}
\hline Part 1: Statements - Effectiveness & $\begin{array}{l}\text { SA } \\
\%\end{array}$ & $\begin{array}{l}\text { A } \\
\%\end{array}$ & $\begin{array}{l}\mathbf{N} \\
\%\end{array}$ & $\begin{array}{l}\text { D } \\
\%\end{array}$ & $\begin{array}{c}\text { SD } \\
\%\end{array}$ & $\begin{array}{c}\text { Agreement } \\
\text { Frequent } \\
\%\end{array}$ \\
\hline 1. ARICOFR is useful in practice & 50 & 35 & 10 & 5 & 0 & 85 \\
\hline $\begin{array}{l}\text { 2. ARICOFR is valuable as a } \\
\text { training device for new auditors }\end{array}$ & 45 & 45 & 5 & 5 & 0 & 90 \\
\hline 3. ARICOFR' $s$ logic is sound & 60 & 30 & 5 & 5 & 0 & 90 \\
\hline $\begin{array}{l}\text { 4. ARICOFR approached the task } \\
\text { of formulating the auditor's } \\
\text { opinion on the effectiveness of } \\
\text { internal controls in the same } \\
\text { manner I would }\end{array}$ & 65 & 25 & 5 & 5 & 0 & 90 \\
\hline $\begin{array}{l}\text { 5. ARICOFR helps auditors better } \\
\text { understand the way they } \\
\text { formulate their opinions on the } \\
\text { effectiveness of internal controls }\end{array}$ & 45 & 45 & 5 & 0 & 5 & 90 \\
\hline $\begin{array}{l}\text { 6. ARICOFR helps auditors } \\
\text { formulate their opinions on the } \\
\text { effectiveness of internal controls } \\
\text { according to COSO's internal } \\
\text { control model }\end{array}$ & 70 & 25 & 5 & 0 & 0 & 95 \\
\hline $\begin{array}{l}\text { 7. ARICOFR provides guidelines } \\
\text { for auditors and management as } \\
\text { to the required procedures to } \\
\text { express their opinions on the } \\
\text { effectiveness of internal controls }\end{array}$ & 60 & 25 & 5 & 5 & 5 & 85 \\
\hline $\begin{array}{l}\text { 8. ARICOFR provides the auditors } \\
\text { with the appropriate auditor's } \\
\text { opinion on the effectiveness of } \\
\text { internal controls }\end{array}$ & 55 & 30 & 5 & 5 & 5 & 85 \\
\hline
\end{tabular}




\begin{tabular}{|c|c|c|c|c|c|c|}
\hline Part 2: Statements - Efficiency & $\begin{array}{l}\text { SA } \\
\%\end{array}$ & $\begin{array}{l}\mathbf{A} \\
\%\end{array}$ & $\begin{array}{l}\mathbf{N} \\
\%\end{array}$ & $\begin{array}{l}\text { D } \\
\%\end{array}$ & $\begin{array}{c}\text { SD } \\
\%\end{array}$ & $\begin{array}{c}\text { Agreement } \\
\text { Frequent } \\
\%\end{array}$ \\
\hline $\begin{array}{l}\text { ARICOFR decreases the } \\
\text { time required for expressing the } \\
\text { auditor's opinion on financial } \\
\text { reports }\end{array}$ & 55 & 15 & 15 & 10 & 5 & 70 \\
\hline Part 3: Statements - Acceptance & $\begin{array}{l}\text { SA } \\
\%\end{array}$ & $\begin{array}{l}\text { A } \\
\%\end{array}$ & $\begin{array}{l}\mathbf{N} \\
\%\end{array}$ & $\begin{array}{l}\mathbf{D} \\
\%\end{array}$ & $\begin{array}{l}\text { SD } \\
\%\end{array}$ & $\begin{array}{c}\text { Agreement } \\
\text { Frequent } \\
\%\end{array}$ \\
\hline $\begin{array}{l}\text { 1. It is easy to follow the logic of } \\
\text { ARICOFR }\end{array}$ & 65 & 20 & 5 & 5 & 5 & 85 \\
\hline $2 . \begin{array}{l}\text { ARICOFR's advice may be } \\
\text { trusted }\end{array}$ & 70 & 20 & 5 & 5 & 0 & 90 \\
\hline $\begin{array}{l}\text { ARICOFR's advice is } \\
\text { professionally accepted }\end{array}$ & 45 & 40 & 10 & 5 & 0 & 85 \\
\hline $\begin{array}{l}\text { 4. ARICOFR needs } \\
\text { improvements }\end{array}$ & 20 & 5 & 30 & 35 & 10 & 40 \\
\hline
\end{tabular}

SA = Strongly Agree, $\mathbf{A}=$ Agree, $\mathbf{N}=$ Neutral, $\mathbf{D}=$ Disagree, SD = Strongly Disagree.

\subsubsection{Effectiveness}

\section{Agreement Frequent \% $=\mathrm{SA} \%+\mathrm{A} \%$}

Effectiveness concerns with the influence of ARICOFR on the decision quality, and high accuracy (Baldwin-Morgan and Stone, 1995; Changchit et al., 2001a). The effectiveness of ARICOFR contains both user-friendliness, which is the system's ability to explain questions and conclusions, and probable usefulness, which is the system's ability to meet an auditor's needs (Baldwin-Morgan and Stone, 1995). From Table 3, part 1, we may conclude that ARICOFR is effective in accomplishing the task of assessing the effectiveness of internal control over financial reporting (Agreement percentage is not less than $85 \%$ ).

\subsubsection{Efficiency}

Efficiency may be determined by the time needed to achieve a task or by the number and administrative levels of individuals involved in the task (Back, 1993-1994; Changchit et al., 2001a). From Table 3, part 2, we may 
conclude that the use of ARICOFR may increase the individual productivity (Agreement percentage is equal to $70 \%$ ).

\subsubsection{Acceptance}

The auditors' acceptance of ARICOFR is affected by the auditors' confidence in the ARICOFR's recommendations and the ease of using ARICOFR (cf. Boritz and Wensley, 1992). From Table 3, part 3, we may conclude that the users have confidence in ARICOFR logic and conclusions (Agreement percentage is not less than 85\%) and ARICOFR still needs some improvements ((Agreement percentage is equal to 25\%).

Lastly, the dependability of the students' answers determined by internal constancy (Coefficient Alpha is 0.787). This means that there is a high constancy among the students' answers on the questions in questionnaire No. 3. During and after the validation, it was clear that the auditors and students were influenced by the result of ARICOFR and by its properties. Furthermore, five experienced auditors proposed several points of how to improve the application of ARICOFR to help auditor formulate the opinion on the internal control over financial reporting and to help management assess the effectiveness of internal controls.

\section{Research Limitations}

The main research limitations are presented below.

- The changes in components of COSO's internal control model will affect the knowledge base of ARICOFR. Therefore, the ARICOFR knowledge base should be continuously updated.

- The knowledge elicitation of ARICOFR is confined to the Egyptian auditors, in particular Egypt does not apply Sarbanes Oxley act.

- The response scale of ARICOFR is restricted to yes or no responses, which may affect the user's attitude in interacting with the system.

- An experimental study should be done to test the impact of ARICOFR (i) on training and educating novices, (ii) on the time required to evaluate the effectiveness of the internal controls, and (iii) on the ease of use.

- The research results depend on Master students' points of view to serve as substitutes for auditors in the evaluation stage. However, if we depend on the auditors within auditing firms, the evaluation results may be different from what had in section 6 . 
- Using test cases only may affect the effectiveness of the ARICOFR; the test cases are designed by the researcher and reviewed by auditors, so some bias may be expected. Using actual auditing cases should be done and may provide different results.

\section{Conclusions and Future Research}

This study describes how we model, implement, and validate of ARICOFR. It answers the questions: (1) can ARICOFR accomplish the task of assessing the internal controls over financial reporting likewise as may be expected from an qualified auditor? If so, (2) how should ARICOFR be built and validated? And (3) to what extent is ARICOFR effective, efficient, and acceptable as an instrument to help auditor assess the effectiveness of internal controls over financial Reporting? From our application, tests, and validations we may conclude two main conclusions: (1) ARICOFR is successful in preparing the auditor's report on internal control over financial reporting, and (2) the nine sub-models embodied in ARICOFR are correct.

More definitely, the students' assessment of the effectiveness, efficiency, and acceptance of ARICOFR are quite positive, i.e., they scored well on our scales. From the reviews of 5 highly qualified auditors in local and international auditing firms in Egypt, we may conclude that the following statements are true: (1) the task of formulating the auditor's opinion on internal control over financial reporting can be achieved by a KBS, and (2) ARICOFR is appropriate and acceptable to express the auditor's opinion on internal control over financial reporting.

Being able to produce a proper auditor's opinion on internal control over financial reporting there are three issues for future study. First, the auditor's requirements should be examined and substantiated. Second, auditors should list a number of recommendations to include in ARICOFR in order to improve the performance any further. Third, ARICOFR should be tested using actual auditing cases. 


\section{References:}

Akoka, J. and Comyn-Wattiau. 1996. A Knowledge-Based System for Auditing Computer and Management Information Systems. Expert System with Applications. 11(3): 361-375.

Ammar, S., Duncombe, W., Jump, B., \& Wright, R. 2004. Constructing a fuzzy-knowledge-based-system: an application for assessing the financial condition of public schools. Expert Systems with Applications 27(23): 349-364.

Arens, A.A., Elder, R.J., and Beasley, M.S. 2014. Auditing and Assurance

Services: An Integrated Approach. 14th Edition, Pearson Education Limited, England.

Asare, S.K., Fitzgerald, B.C., Graham, L.E, Joe, J.R., Negangard, E.M and Wolfe, C.J. 2013. Auditors' Internal Control over Financial Reporting Decisions: Analysis, Synthesis, and Research Directions, Auditing: A Journal of Practice \& Theory. 32(1): 131-166.

Asare, S.K. and Wright, A. 2012. The effect of Type of internal Control Report on users' Confidence in the Accompanying Financial Statement Audit report. Contemporary Accounting research 29 (1): 152-175.

Back, B. 1993-1994. Validating an Expert System for Financial Statement Planning. Journal of Management Information Systems 10 (3): 157177.

Baldwin-Morgan, A.A. and Stone, M.F. 1995. A Matrix Model of Expert Systems Impacts. Expert Systems with Applications 9 (4): 599-608.

Bao, D., \& Yang, Z. 2008. Intelligent stock trading system by turning point confirming and probabilistic reasoning. Expert Systems with Applications 34 (1): 620-627.

Bayraktar, D. 1998. A Knowledge-Based Expert System Approach for the Auditing Process of Some Elements in the Quality Assurance System. International Journal of Products Economics 56-57:37-46.

Boritz, J. E. and Wensley, A.K. 1992. Evaluation Expert Systems with Complex Outputs: The Case of Audit Planning, auditing. A Journal of Practice \& Theory: 11(2): 4-29. 
Boynton, W.C. and Johnson, R.N. 2006. Modern Auditing- Assurance Services and The Integrity Of Financial Reporting. John Wiley \& Sons, Inc., 8th Edition.

Brown, C.E and Murphy, D.S. 1990. The Use of Auditing Expert Systems in Public Accounting. Journal of Information Systems 4(3): 63-73.

Brown, C.E. and O'Leary, D.E. 1995. Introduction to Artificial Intelligence and Expert Systems, Available at http://accounting.rutgers.edu/raw/aies/ (downloaded in March 24, 2004).

Brown, D. and Eining, M. 1997. Judgment and Decision Making, Part IV: Information Technology and Decision Aids. Behavioral Accounting Research Foundations and Frontiers: 164-187, American Accounting Association, Sarasota, Florida.

Changchit, C., Holsapple, C. W., and Viator, R.E. 2001a. Transferring Auditors' Internal Control Evaluation Knowledge to Management. Expert System with Applications 20:275-291.

Changchit, C., Holsapple, C.W., and Madden, D.L. 2001b. Supporting Managers' Internal Control Evaluations: An Expert System and Experimental Results. Decision Support Systems 30: 437-449.

Chen, J. K., \& Chen, I. S. 2010. A Pro-performance appraisal system for the university. Expert Systems with Applications 37(3): 2108-2116.

Cheng, H., Lu, Y. C., \& Sheu, C. 2009. An ontology-based business intelligence application in a financial knowledge management system. Expert Systems with Applications 36(2): 3614-3622.

Choy, K. L., Chow, H. K. H., Tan, K. H., Chan, C.-K., Mok, E. C. M., \& Wang, Q. 2008. Leveraging the supply chain flexibility of third party logistics - hybrid knowledge-based system approach. Expert Systems with Applications 35(4): 1998-2016.

Chung, W. W. C., \& Pak, J. J. F. 2006. A case study: using UML to develop a knowledge-based system for supporting business systems in a small financial institute. International Journal of Computer Integrated Manufacturing 19(1): 59-68.

Colbert, J.L. 2000. The Impact of The New External Auditing Standards. Internal Auditor 57(6): 46-51. 
Collier, P.A., Leech, S.A., and Clark, N. 1999. A Validation Expert System for Decision Making in Corporate Recovery. International Journal on Intelligent Systems in Accounting. Finance \& Management 8: 75-88.

Curtis, M.B. and Hayes, T. 2002. Materiality and Audit Adjustments. The CPA Journal, www.nysscpa.org/cpajournal/2002/0402/dept/d046902.html/(downloaded in May 15, 2005).

Davis, J.T., Ramamoorti, S. \& Krull, G.W. (2017). Understanding, Evaluating, and Monitoring Internal Control Systems: A case and Spreadsheet Based Pedagogical Approach. AIS Educator Journal, 12(1), 59-68. https://doi.org/10.3194/1935-8156-12.1.59

Egerdahl, R.L. 1995. A Risk Matrix Approach to Data Processing Facility Audits. Internal Auditor 52(3): 34-41.

Ernst \& Young 2002. Comparison IFRS with Dutch Law and Regulations, Ernst \& Young Accountants, Rotterdam, The Netherlands. Available at http:// www.ey.com, (downloaded in June 20, 2004).

Flory, S.M. 1991. Here's an Expert System-Based Support Tool for Making Accounting Decisions. The CPA Journal Online (downloaded in October 10, 2003).

Gaber, M., Garas, S. \& Lusk, E.J. 2019. Evidence on the Impact of Internal Control over Financial Reporting on Audit Fees, International Journal of Accounting and Financial Reporting 9(3): 123.

Gunawan, A. 2012. Information Access for SMEs in Indonesia: A study on the Business Performance of Garment Manufacturers. Doctoral Thesis, Tilburg University.

Guy, D.M., Carmichael, D.R., and Lach, L.A. 2003. Practitioner's Guide to GAAS. John Wiley and Sons, Inc., Canada.

Han, S., Rezaee, Z., Xue, L., \& Zhang, J.H. (2015). The Association between Information Technology Investments and Audit Risk, Journal of Information Systems. Available at: http://dx.doi.org/10.2308/isys-51317, Accessed on: 2/2/2016. https://doi.org/10.2308/isys-51317 
Hayes, R., Dassen, R., Schilder, A., and Wallage, P. 2005. Principles of Auditing: an Introduction to International Standards on Auditing. FT Prentice Hall, Amsterdam.

Hegazy, M. 1992. The Expert AOF: A Rule-Based Expert System for Audit opinion Formation, MSc. Thesis, Department of Artificial Intelligence, University of Edinburgh.

Herik, H.J. van den 1988. Informatica en het menselijk blikveld. Inaugural address Rijksuniversiteit Limburg, Maastricht, The Netherlands.

Huang, H. C. 2009. Designing a knowledge-based system for strategic planning: A balanced scorecard perspective. Expert Systems with Applications 36(1): 209-218.

Hwang, S., Shin, T., \& Han, I. (2004). Internal Control Risk Assessment System Using Case-Based Reasoning. Expert Systems, 21(1), 22-33. https://doi.org/10.1111/j.1468-0394.2004.00260.x

IFAC 2010. Handbook of International Auditing, Assurance, and Ethics Pronouncements. International Federation of Accountants. Available at http:/www.ifac.org

Institute of internal Auditors. 2008. Sarbanes-Oxley Section 404: A guide for management by internal Controls practitioners, 2nd Edition, January.

Jacob, V.S. and Bailey, A.D. 1991. A Conceptual Framework for the Network Approach to Expert Systems Development in Auditing. Information Processing and Management 27(5): 481-497.

Jayanthi, R., \& Vishal, B. 2011. Role of knowledge management and analytical CRM in business: data mining based framework. The Learning Organization18(2): 131-148.

Jones, S.R. and Miles, J.C. 1998. The Use of a Prototype System for Evaluating Knowledge Elicitation Techniques. Expert Systems 15(2): 83-97.

Khan, M. K., \& Wibisono, D. 2008. A hybrid knowledge-based performance measurement system. Business Process Management Journal 14(2): 129 - 146.

Killingsworth, L.B., Hayden, M.B., and Schellenberger, R. 2001. A Network Expert System Management System for Multiple Domains, Journal of Information Science 27(2): 81-92. 
Krishnan, G.V. and Visvanathan, G. 2007. Reporting Internal Control Deficiencies in the post-Surbanes-Oxley Era: The Role of auditors and Corporate governance. International journal of auditing 11: 7390.

Kumra, R., Stein, R. M., \& Assersohn, I. 2006. Assessing a knowledgebased approach to commercial loan underwriting. Expert Systems with Applications 30(3): 507-518.

Lee, A. H. I. 2009. A fuzzy supplier selection model with the consideration of benefits, opportunities, costs and risks. Expert Systems with Applications 36(2): 2879-2893.

Lenard, M.J. 2003. Knowledge Acquisition and Memory Effects involving an Expert System Designed as a Learning Tool for Internal Control Assessment. Decision Sciences Journal of Innovative education 1(1): 23-38.

Lenard, M.J., Alam, P., Booth, D., and Madey, G. 2001. Decision-Making Capabilities of a Hybrid System Applied to the Auditor's GoingConcern Assessment. International Journal on Intelligent Systems in Accounting, Finance \& Management 10: 1-24.

Lenard, M.J., Madey, G.R., and Alam, P. 1998. The Design and Validation of a Hybrid Information System for the Auditor's Going Concern Decision. Journal of Management Information Systems 14(4): 219237.

Locatelli, M. 2002. Good Internal Controls and Auditor Independence. The CPA Journal, (October): 12-15.

Lopez, T.J., Vandervelde, S.D. and Wu, Y. 2006. The Auditor's Internal Control Opinions: An Experimental Investigation of Relevance. ABC Conference and THE University of South Caroline, Columbia: $1-27$.

Mak, B., Schmitt, H., and Lyytinen, K. 1997. User Participation in Knowledge Update of Expert Systems. Information \& Management 32: $55-63$.

Manson, S. and Zaman, M. 2001. Auditor Communication in an Evolving Environment: Going Beyond SAS 600 Auditors' Reports on Financial statements. British Accounting Review 33: 113-136. 
Marand, A.A. \& Bayaz, M.L.D. (2015). Survey the Effect of the Computerized Accounting Systems on the Auditing Risk Management. International Journal of Review in Life Sciences, 5(10), 607-618.

Mattei, M.D. 2001. Using Expert Systems for Competitive Advantage. Business and Economic Review 47(3), (Apr-Jun).

Messier, W.F. and Hansen, J.V. 1992. A Case Study and Field Evaluation of EDP-XPERT. Intelligent Systems in Accounting, Finance, and Management 1: 173-185

Munter, P. 2003. Evaluating Internal Controls and Auditor Independence under Sarbanes-Oxley. Financial Executive (October): 25-26.

O'Leary, D.E. 2003. Auditor Environmental Assessments. International Journal of Accounting Information Systems 4: 275-294.

PCAOB. 2007. An Audit of Internal Control over Financial Reporting Performed in Conjunction with an Audit of Financial Statements. Washington, DC, PCAOB Release 2007-005A, PCAOB Rulemaking, Docket Matter No.021.

Poh, K. L. 2000. An intelligent decision support system for investment analysis. Knowledge and Information Systems 2: 340-358.

Post, W., Wielinga, B.J., and Schreiber, G. 1997. Organizational Modeling in Common KADS: The Emergency Medical Service. IEEE Expert: 46-52.

Romney, M.B. and steinbart, P.J. 2012. Accounting Information Systems, Pearson Education Limited, 12 th, london.

Schreiber, G., Wielinga, B.J., and Breuker, J. 1993. KADS, A Principled Approach to Knowledge-Based System Development. Academic Press "AP", Harcourt Brace Javanovich, Publishers, London.

Shaalan, K., Rafea, M., and Rafea, A. 1998. KROL: a Knowledge Representation Object Language on top of Prolog. Expert System with Applications 15: 33-46.

Shiue, W., Li, S. T., \& Chen, K. J. 2008. A frame knowledge system for managing financial decision knowledge. Expert Systems with Applications 35(3): 1068-1079.

Smith, L.M. and McDuffie, R. S. 1996. The Use of an Audit Reporting Expert System in the Classroom. Presented at the Southwest 
American Accounting Association Annual Meeting, San Antonio, http://acct.tamu.edu/smith/audport/intro.htm. (downloaded in August 10, 2004).

Steinbart, P.J. 1987. The Construction of a Rule-Based Expert System as a Method for Studying Materiality Judgments. The Accounting Review LXII(1): 97-116.

Vinze, A.S. and Karan, V., A. 1991. A Generalizable Knowledge-Based

Framework for Audit Planning Expert Systems, Journal of Information Systems 5(2): 78-92.

Wahdan, M. A. 2006. Automatic Formulation of the Auditor's Opinion.

PhDThesis. Maastricht, the Netherlands: Maastricht University.

Wahdan, M.A., 2018. Impact of a Practical Flowcharts Approach on Educating the Control Risk Assessment, Accounting and Finance Research. 7(2): 1-18.

Wahdan, M. A.,\&, Hassan, M. 2019. Automatic Assessment of Materiality: A Knowledge-based Approach, International Journal of Computer Auditing, 1(1): 64- 91.

Wahdan, M.A., Spronck, P., Ali, H. F., Vaassen, E., and Herik, H.J. van den 2005. When Will a Computer Write the Auditor's Report. The Journal of Systemic Practice and Action Research 18(6): 569-580.

Wahdan, M. \& Van den Herik, H. J.2012, Egyptian auditing Investigated:

Diagnoses and Remedies. International Journal of Economics and Accounting 3(314): 365-389.

Wang, W. K., Huang, H. C., \& Lai, M. C. 2008. Design of a knowledgebased performance evaluation system: a case of high-tech stateowned enterprises in an emerging economy. Expert Systems with Applications 34(3): 1795-1803.

Wen, W., Wang, W. K., \& Wang, C. H. 2005. A knowledge-based intelligent decision support system for national defense budget planning. Expert Systems with Applications, 28(1): 55-66.

Whittington, O.R. and Pany, K. 2003. Principles of Auditing and Other Assurance Services, Mc Graw Hill, Boston.

Yuan, F.-C. 2009. The Use of a Fuzzy Logic-based System in Cost-VolumeProfit Analysis under uncertainty. Expert Systems with Applications 36(2): 1155-1163. 